У, 342

ББK 67.400

DOI 10.22394/1682-2358-2018-3-12-20

G.N. Kopyatina, lecturer of the Jurisprudence Department, North-West Institute of Management, Branch of the Russian Presidential Academy of National Economy and Public Administration

\section{CONSTITUTIONAL \\ EQUALITY \\ OF SUBJECTS \\ OF THE RUSSIAN \\ FEDERATION \\ AS A MEANS \\ OF ENSURING \\ THE UNITY} OF A FEDERAL STATE

Preservation of state integrity is viewed through the principles of state power unity and equality of subjects of the Russian Federation among themselves and in relations with the Russian Federation. Particular attention is paid to equalizing the legal status of the republics and other subjects of the Russian Federation and weakening the asymmetry of the Russian Federation.

Key words and word-combinations: federal relations, equality of the subjects of the Russian Federation, asymmetry of federal relations.
Г.H. Копатина, стариий преподаватель кафедрь правоведения Северо-Западного института управления - филиала Российской академии народного хозяйства и государственной службь при Президенте РФ (email: gul-kор@ yandex.ru)

\section{КОНСТИТУЦИОННОЕ РАВНОПРАВИЕ СУБЪЕКТОВ РОССИЙСКОЙ ФЕАЕРАЦИИ KAK CPEАСТВO ОБЕСПЕЧЕНИЯ ЕАИНСТВА ФЕАЕРАТИВНОГО ГОСУААРСТВА}

Аннотация. Сохранение государственной целостности рассматривается через призму принципов единства государственной власти и равноправия субъектов РФ между собой и во взаимоотношениях с Российской Федерацией. Особое внимание уделяется выравниванию правового положения республик и других субъектов РФ, а также ослаблению асимметричности Российской Федерации.

Ключевые слова и словосочетания: федеративные отношения, равноправие субъектов РФ, асимметрия федеративных отношений.

оохранение государственной целостности Российской Федераџии - одна из основных конституционных ценностей Российского государства, заключающаяся в намичии трех компонентов: территориальной целостности, еАинстве конституционно-правовой системы и единстве государственной 
власти. Единство государственной власти явцяется важнейшим признаком џемостности государства. Особую значимость принцип единства приобретает в период построения федеративного государства.

На рубеже 1980-1990-х годов в России возникла угроза распада РСФСР. В результате борьбы за власть с целью ослабления России в циџе Б.Н. Ецьџина, М.С. Горбачёвым бымо преАложено поднять статус автономных образований в составе РСФСР Ао правового положения союзных республик [1, с. 127] . Верховный Совет СССР поддержал данную инициативу принятием Закона «Об основах экономических отношений Союза ССР, союзных и автономных республик» [2]. После принятия Закона автономные республики выступают за уравнение прав автономных республик с союзными республиками.

Посме принятия Закона СССР от 26 апремя 1990 г. «О разграничении полномочий между Союзом ССР и субъектами Федерации» [3] все автономные республики были провозглашены государствами с оговоркой о том, что они явмяются субъектами Федерации - Союза ССР. В законах РСФСР четыре автономные области, кроме Еврейской, были преобразованы в республики в составе РСФСР. Соответствующие изменения были внесены и в Конституцию РСФСР Законом РСФСР от 3 июля 1991 г. № 1540-1 «Об изменениях и дополнениях Конститущии (Основного Закона) РСФСР в связи с преобразованием автономных областей в Советские Соџиалистические Республики в составе РСФСР» [4] . Союзные органы власти проявцяли цояльность по отношению органам власти автономных республик, получая в их мице поддержкку при урегулировании взаимоотношений с союзными республиками [5]. Конфликтность взаимоотношений союзного центра и союзных республик была отражена в законодательстве.

Часть автономий в составе РСФСР получияи возможность приобрести статус государств и были преобразованы в союзные республики в составе Союза ССР [6, с. 12], что усилило асимметрию автономных государственных образований и административно-территориальных единиц в составе РСФСР, создав угрозу ее территориальной цемостности. Учитывая возможность распада РСФСР, Амя обеспечения государственной цемостности, приоритета российских законов над законами Союза ССР 12 июня 1990 г. Съездом народных депутатов РСФСР была принята Аеклараџия о государственном суверенитете РСФСР [7] .

В 1990-1991 гг. республики Татарстан, Башкирия и Якутия, обладавшие большим запасом природных ресурсов, были самыми настойчивыми в вопросе предоставления им суверенитета. Конфликтность отношений межАу органами власти РСФСР и республиками в составе РСФСР повлекли принятие в 1990 г. Аеклараџий о государственном суверенитете во многих республиках, кроме Аагестана, Карачаево-Черкесии и Ингушетии (прежде входившей в состав Чечено-Ингушской АССР). [8] Руководители органов власти РСФСР вынуждены были считаться с влиятельными главами республик, предоставцяя также региональным органам власти возможности самостоятельного решения вопросов структуры органов власти. 
События августа 1991 г. способствовали проявлению противодействия региональных мидеров политике руководства России. Хотя Президент СССР берет на себя руководство союзным государством, тем не менее большая часть вопросов переходит в ведение РСФСР, что усиливает полномочия Президента РСФСР. В этих условиях руководством РСФСР принимается ряА мер по укрепцению власти в России, по обеспечению единства в деятельности органов исполнительной власти в РСФСР, в том числе на территориях, входящих в состав РСФСР. Верховный Совет РСФСР принимает постановление от 21 августа 1991 г. № 1626-1 «О дополнительных полномочиях Президента РСФСР по обеспечению законности деятельности Советов народных депутатов в условиях Аиквидации последствий попытки государственного переворота в СССР» [9], где указано, что Президент РСФСР и виџе-президент РСФСР, Совет Министров РСФСР, советы министров республик в составе РСФСР, иные органы исполнительной власти и должностные Аиџа - главы исполнительной власти образуют единую систему исполнительной власти в РСФСР.

Президентом РСФСР также принимаются меры по обеспечению единства исполнительной власти, результатом которых явилось подписание Указа от 22 августа 1991 г. № 75 «О некоторых вопросах деятельности органов исполнительной власти в РСФСР» [10], в соответствии с которым в краях, областях, автономной области, автономных округах вводится домжность главы администрации, а также устанавливается право Президента РСФСР, по согласованию с соответствуюшим Советом народных депутатов, назначать на должность глав администраций и освобождать их от Аомжности по своей инициативе до принятия закона РСФСР об управлении краем, областью в РСФСР, законов РСФСР об автономных областях, автономных округах в РСФСР. В соответствии с данным Указом в краях, областях, автономной области, автономных округах назначение глав администраџий производимось Президентом РСФСР, при этом в соответствии с Законом РСФСР от 1 ноября 1991 г. № 1827-1 «Об изменениях и дополнениях Конституции (Основного Закона) РСФСР» [11] в республиках в составе РСФСР полномочия, порядок избрания и деятельности глав исполнительной власти (президентов) республик в составе РСФСР определяются конституциями и законами республик в составе РСФСР. Несмотря на предоставленное право избрания президента республики, в соответствии с законом РСФСР от 1 ноября 1991 г. № 1827-1 только в отношении республик в Конституции РСФСР 1987 г. закрепцялось, что глава исполнительной власти (президент) республики в составе РСФСР входит в единую систему исполнительной власти РСФСР, возглавляемую Президентом РСФСР.

31 декабря 1992 г. быц подписан Федеративный договор о разграничении предметов ведения и полномочий [12], в котором предметы ведения раздемямись межАу федеральными органами власти Российской Федераџии и органами власти ее территориальных образований. Федеративный договор выступил в качестве среАства временного ослабления противоречий во внутреннем устройстве Российской Федерации, при этом, в названии Федеративного Аоговора, подписанного с полномочными представителями республик в составе Российской Федерации, говорится о «суверенных республиках». 
В Конституцию РСФСР 1978 г. Законом РФ от 21 апреля 1992 г. № 2708-1 [13] были внесены изменения, повлекшие неравенство правового статуса субъектов Федерации, в связи с закреплением ряда преимуществ за республиками по сравнению с Аругими субъектами. В данном Законе РФ республики были названы государствами, обладавшими всей полнотой государственной власти, полномочия которых ограничивались ведением федеральных органов государственной власти Российской Федерации. За республиками закреплялось право иметь Конституцию и принимать законы в отличие от краев, областей, автономной обцасти, автономных округов, городов Москвы и Санкт-Петербурга, которые принимали иные нормативно-правовые акты. Несмотря на ряд преимуществ республик, в ч. 2 ст. 132.1 Конститущии РФ 1978 г. подчеркивается, что глава исполнительной власти (президент) республики в составе Российской Федераџии входит в единую систему исполнительной власти Российской Федерации, возглавмяемую Президентом Российской Федерации.

Развитие федеративных отношений рассматриваемого периода по отношению к респубцикам обцадает рядом особенностей вследствие того, что в 1990 г. автономные и союзные республики были уравнены в правах, а также вследствие политики суверенизации республик в составе РСФСР, в результате которой возникла угроза обретения ими самостоятельности и выхода из состава РСФСР. В Аанный период угроза нарушения территориальной целостности сохранялась вследствие сепаратистских тенденџий ряда субъектов РФ, в особенности республик. Федеративный договор 1992 г. не способствовац установлению симметричных федеративных отношений, так как закреплял суверенный статус республик в составе России. Сохранение государственного единства Российской Федерации требовало исправления асимметрии, созданной в РСФСР, путем выравнивания правового положения республик и Аругих территориальных образований Российской Федеращии. При этом важно собАюдать ориентированность государства на учет интересов многонаџионального народа, проживающего в национальных республиках и других территориальных образованиях.

Принятие Конститущии РФ 1993 г. [14] изменимо политическую и правовую ситуацию в стране. В отличие от Конституции РСФСР 1978 г. принцип единства государственной власти, закреплен в отношении всех субъектов Российской Федерации, а не только республик в главе 1 «Основы конституџионного строя», что подтверждает значимость данного принципа наравне с Аругими принџипами, закрепленными в Конститущии РФ.

Эволюџионные процессы обеспечения единства государственной власти в России в данный период времени характеризуется выстраиванием взаимоотношений межАу органами государственной власти Российской Федераџией и органами государственной власти субъектов РФ, основанном на принципе равенства субъектов Федерации. На примере выборов (назначения) глав субъектов РФ четко прослеживается выстраивание единства государственной власти межлу Российской Федераџией и субъектами РФ, так как высшее должностное Аиџо является џентральным звеном в системе организаџии вцасти в субъектах Российской Федераџии. 
Согласно ч. 2 ст. 11 Конституции РФ субъекты РФ самостоятельно образовывают систему органов государственной вмасти в регионе, но в Основном Законе не прописан способ формирования органов власти в субъектах РФ. Вопрос о выборах или назначении главы субъекта РФ оставался неурегумированным на законодательном уровне. При этом установленная система органов государственной власти должна соответствовать основам конституционного строя и общим принципам организаџии преАставительных и исполнительных органов государственной власти, закрепленным в федеральном законе (ч. 1 ст. 77 Конституции РФ), который еще не был принят.

В 1993-1994 гг. проходят выборы в региональные пармаменты и возникает вопрос о назначении выборов глав субъектов РФ. В условиях сложных политических взаимоотношений между федеральной властью и регионами, Президентом РФ был издан Указ от 3 октября 1994 г. «О мерах по укреплению единой системы исполнительной власти в Российской Федерации». Абзаџ второй п. 2 Указа содержал положение о том, что «вопрос о назначении выборов главы администрации края, области, города федерального значения, автономной обцасти, автономного округа, пока иной порядок не будет установлен федеральным законодательством, решается Президентом Российской Федерации» [15] . Принятие Указа Президента РФ от 3 октября 1994 г. было необходимо в связи с переходным периодом, до формирования федерального законодательства об основах взаимоотношений между федеральными органами государственной власти и органами государственной власти субъектов Федераџии. Аанная позиџия Президента РФ, закрепленная в Указе, быка направлена на укрепление исполнительной власти и стабильности государства.

В соответствии с Указом от 3 октября 1994 г. в ряде субъектов РФ, принявших уставы, конституции и избирательные законы, выборы проведены не были из-за отсутствия соответствуюшего разрешения Президента РФ, хотя в Аругих субъектах при аналогичных условиях выборы состоямись. Как отмечает К.В. Черкасов, «вплоть до осени 1996 г. выборы глав исполнительной власти были привияегией, которые одни субъекты России получали в силу сложившегося особого правового статуса (республики, города федерального значения), а Аругие - в порядке исключения за заслуги их руководства переА главой государства». [16] Таким образом, субъекты РФ были поставлены в неравное положение, о чем было указано в постановлении Конституционного Суда РФ от 30 апреля 1996 г. № 11-П [17]. После выборов Президента РФ в 1996 г. выборы глав регионов были проведены повсеместно.

Происходившие события, связанные с децентрализацией власти, повлияли на установление демократических основ управления государством, но змоупотребление властью со стороны глав регионов и несоблюдение общефедеральных норм ослабляло единство государственной власти в Российской ФеАерации и требовало принятия федерального закона, опредемявшего правовые взаимоотношения межАу Российской Федерацией и субъектами Российской Федерации.

Ао принятия Федерального закона от 24 июня 1999 г. 119-Ф3 «О принципах и порядке разграничения предметов ведения и полномочий между органами 
государственной власти Российской Федерации и органами государственной вмасти субъектов Российской Федерации» [18] правовое регулирование взаимоотношений межАу Российской Федерацией и субъектами РФ осуществцямось посреАством заключения договоров межАу федеральными органами власти и региональными. Аоговоры о разграничении предметов ведения и полномочий между органами государственной власти Российской Федерации и органами государственной власти субъектов РФ ставици в неравное положение субъекты РФ межАу собой и по отношению к Российской Федераџии, что приводияо к усилению асимметрии федеративного устройства Российской Федераџии.

Конститущия РФ, закрепив в п. 4 ст. 5 равное правовое положение субъектов РФ межАу собой и во взаимоотношениях с федеральными органами государственной власти, заложила основу Аля укрепления государственного единства России. Несмотря на это, асимметрия в федеративных отношениях еще не была преодомена.

С 2000 г. начинается период централизации власти, который связан с сохранением государственной целостности государства, а следовательно, с укреплением единства системы государственной власти. Заложенный в 1993 г. Конституџией РФ потенџиал реализаџии принципа единства государственной власти Российской Федерации и субъектов РФ не быц освоен законодательно в период с 1993 по 2000 г., поэтому принятие Федерального закона от 6 октября 1999 г. № 184-Ф3 «Об общих принщипах ...» [19] направлено на развитие федеративных отношений, на приведение в соответствие законодательства субъектов Российской Федерации с федеральным законодательством. Федеральный закон от 6 октября 1999 г. № 184-Ф3 «Об общих принџипах ...» создает возможности дмя установления единства федеративного государства, обеспечения равноправия субъектов РФ межАу собой и во взаимоотношениях с Российской Федераџией.

В 2003-2004 гг. в Федеральный закон от 6 октября 1999 г. № 184 «Об общих принципах ...» были вкмючены нормы, о наделении полномочиями главы субъекта законодательным органом субъекта РФ, которые были вызваны необходимостью укрепления единой системы исполнительной власти в Российской Федераџии. С целью повышения ответственности органов государственной власти субъектов РФ в Федеральном законе от 6 октября 1999 г. № 184-Ф3 «Об общих принципах ...» была предусмотрена возможность Аосрочного прекрашения полномочий высшего Аолжностного Аиџа субъекта РФ в связи с выражением ему недоверия законодательным органом субъекта РФ, а также возможность отрешения от домжности глав субъектов Федерации Президентом РФ. Эти изменения были обусловмены необходимостью построения единой системы органов исполнительной власти в Российской Федерации и субъектах РФ.

Федеральный закон от 06 октября 1999 г. № 184-Ф3 «Об общих принципах ...» устанавливает принщипы и порядок заключения договоров и соглашений о разграничении полномочий в случае, если особенности субъекта РФ обуславливают разграничение полномочий иначе, чем это предусмотрено федеральными законами и законодательством субъекта Федераџии. В 2000-х годах начался отказ от заключенных ранее и пролонгации уже имеющихся договоров между феде- 
ральным центром и субъектами Федерации, которые не соответствуют требованиям Федерального закона от 6 октября 1999 г. № 184-Ф3 «Об общих принщипах ...». С одной стороны, "договорное право в России было практически сведено на нет» [20, с. 308] , с Аругой стороны, способствовало выравниванию правового положения субъектов РФ во взаимоотношениях межАу Российской Федерацией и межлу собой. Несмотря на усиление унификации российского законодательства вследствие приведения законодательства субъектов РФ в соответствие с законодательством Российской Федераџии, массовое аннулирование внутрифедеративных вертикальных договоров способствовало обеспечению единства законодательной базы федеративного государства, стабилизаџии федерального и регионального законодательства, ослаблению асимметричности Российской Федерации.

Тенденции развития законодательства начала 2000-х годов заключаются в следуюшем: во-первых, законодательство субъектов РФ приводится в соответствие с федеральными правовыми нормами, устанавливающими общие принщипы организаџии власти в субъектах РФ и основы взаимоотношений межАу органами государственной власти Российской Федерации и субъектов РФ; вовторых, ограничение Аоговорного регулирования взаимоотношений Российской Федерации и субъектов РФ способствовало укреплению принципа равноправия субъектов Федерации во взаимоотношениях с федеральными органами государственной вмасти и межАу собой.

В первом десятилетии XXI в. тенденция централизации власти начала преобладать, что мешало полноценному развитию федеративных отношений в России. Именно поэтому с 2010 г. федеральные органы власти берут курс на децентрализацию федеративных отношений в России, выражающуюся в снижении требований Аля регистраџии политических партий [21], допуску к распредемению депутатских мандатов в Государственной Ауме РФ политических партий, набравших пять и более проџентов голосов избирателей [22], в возможности альтернативного подхода к выборам высшего должностного миџа субъекта РФ, объединению Высшего Арбитражного и Верховного судов РФ.

С 1 июня 2012 г. вступил в силу Федеральный закон от 2 мая 2012 г. № 40-Ф3 «О внесении изменений в Федеральный закон «Об общих принципах организации законодательных (представительных) и исполнительных органов государственной власти субъектов Российской Федерации» [23] и Федеральный закон «Об основных гарантиях избирательных прав и права на участие в референдуме гражАан Российской Федерации», в котором главы субъектов РФ избираются населением непосредственно, но отбор кандидатур на Аолжность главы субъекта РФ может проводиться с участием Президента РФ. В 2013 г. в статью 18 Федерального закона от 6 октября 1999 г. № 184-Ф3 «Об общих принщипах ...» [24] были внесены изменения, касающиеся избрания высшего домжностного мица субъекта РФ законодательным органом субъекта РФ, а кандидатуры на должность главы субъекта РФ представляются в законодательный орган Президентом РФ по предложениям политических партий. Система выборов глав субъектов РФ преАставительным органом власти используется в нескольких регионах, из них в республиках: Аагестан, Ингушетия, Кабардино-Балкария, Карачаево-Черкесия, 
Северная Осетия - Алания. Население выбирает глав субъектов РФ как непосредственно, так и опосредованно, через представителей в законодательном органе власти субъекта РФ. Закрепляя оба способа выборов главы субъекта РФ, в которых Президент РФ принимает непосредственное участие, законодатель подчеркивает его особую роль в выстраивании федеративных отношений.

В 2017 г. истек срок действия Аоговора между Российской Федерацией и Республикой Татарстан «О разграничении предметов ведения и взаимном делегировании полномочий между органами государственной власти Российской Федерации и органами государственной власти Республики Татарстан», утвержкенный Федеральным законом от 24 июля 2007 г. № 199-Ф3 [25], который оставался единственным действовавшим договором межАу Российской Федераџией и республикой. Прекращение договорного регулирования взаимоотношений Российской Федераџии и субъектов РФ способствует ослабмению асимметрии в федеративном устройстве российского государства.

Таким образом, сохранение государственного единства Российской Федерации обеспечивается конституционным равноправием субъектов Российской Федераџии. В то же время достижение правового равенства регионов не Аолжно препятствовать учету их экономических, географических и иных особенностей. Асимметрия является неотъемлемой составмяющей конституционно-правового статуса субъектов РФ, она отражена в Конститущии РФ 1993 г. и обусловлена историческими процессами формирования Российской Федерации. Государство, закрепляя принџип единства государственной власти, обеспечивает сочетание интересов Российской Федераџии и субъектов РФ, и прежде всего самостоятельное осуществление ими государственной власти с учетом исторических, национальных и иных традиџий.

\section{Библиографический список}

1. Шахрай С.М., Станских С.Н. Мифология распада СССР // Журнал российского права. 2010. № 1. C. 127-137.

2. Об основах экономических отношений Союза ССР, союзных и автономных республик: Закон СССР от 10 апр. 1990 г. № 1421-1 // Ведомости СНД СССР и ВС СССР. 1990. № 16. Ст. 270 (утратил силу).

3. О разграничении полномочий между Союзом ССР и субъектами Федерации: Закон СССР от 26 апр. 1990 г. // Ведомости СНД СССР и ВС СССР. 1990. № 19. Ст. 32 (утратил силу).

4. Об изменениях и дополнениях Конституции (Основного Закона) РСФСР в связи с преобразованием автономных областей в Советские Социалистические Республики в составе РСФСР: Закон РСФСР от 3 июля 1991 г. № 1540-1 // Ведомости СНД и ВС РСФСР. 1991. № 27. Ст. 935 (утратил силу).

5. Авакьян С.A. Конституция России: природа, эволюция, современность. 2-е изд. М., 2000.

6. Лукьянова Е.A. «Золотая середина» российского централизма, или еще раз об истоках федеративной природы России // Право: журнал Высшей школы экономики. 2015. № 1. С. 4-21.

7. О государственном суверенитете Российской Советской Федеративной Социалистической Республики: Декларация СНД РСФСР от 12 июня 1990 г. № 22-1 // Ведомости СНД и ВС РСФСР. 1990. № 2. Ст. 22.

8. Прохоров К.В. Становление исполнительной власти в Российской Федерации в условиях федерализма // Административное и муниципальное право. 2009. № 4. С. 31-40.

9. О дополнительных полномочиях Президента РСФСР по обеспечению законности деятельности Советов народных депутатов в условиях ликвидации последствий попытки госу- 
дарственного переворота в СССР: постановление Верховного Совета РСФСР от 21 авг. 1991 г. № 1626-1 // Ведомости СНД и ВС РСФСР. 1991. № 34. Ст. 1125.

10. О некоторых вопросах деятельности органов исполнительной власти в РСФСР: Указ Президента РСФСР от 22 авг. 1991 г. № 75 // Ведомости СНД и ВС РСФСР. 1991. № 34. Ст. 1146 (недействующая редакция).

11. Об изменениях и дополнениях Конституции (Основного Закона) РСФСР: Закон РСФСР от 1 нояб. 1991 г. № 1827-1 // Ведомости СНД и ВС РСФСР. 1991. № 45. Ст. 1497 (утратил силу).

12. Федеративный договор: Документы. Комментарий. М., 1994.

13. Об изменениях и дополнениях Конституции (Основного Закона) Российской Советской Федеративной Социалистической Республики: Закон РФ от 21 апр. 1992 г. № 2708-1// Ведомости СНД и ВС РФ. 1992. № 20. Ст. 1084.

14. Конституция Российской Федерации от 12 дек. 1993 г. (в ред. от 21 июля 2014 г. № 11ФКЗ) // СЗ РФ. 2014. № 31. Ст. 4398; С3 РФ. 2014. № 31. Ст. 4398.

15. О мерах по укреплению единой системы исполнительной власти в Российской Федерации: Указ Президента РФ от 3 окт. 1994 г. № 1969 // СЗ РФ. 1994. № 24. Ст. 2598 (утратил силу).

16. Черкасов K.B. Межрегиональное государственное управление в России в условиях становления современной правовой системы? // Гражданин и право. 2011. № 6. С. 15-25.

17. По делу о проверке конституционности пункта 2 Указа Президента Российской Федерации от 3 октября 1994 г. № 1969 «О мерах по укреплению единой системы исполнительной власти в Российской Федерации» и пункта 2.3 Положения о главе администрации края, области, города федерального значения, автономной области, автономного округа Российской Федерации, утвержденного названным Указом: постановление Конституционного суда РФ от 30 апр. 1996 г. № 11-П // С3 РФ. 1996. № 19. Ст. 2320.

18. О принципах и порядке разграничения предметов ведения и полномочий между органами государственной власти Российской Федерации и органами государственной власти субъектов Российской Федерации: Федер. закон от 24 июня 1999 г. № 119-ФЗ (в ред. от 20 мая 2002 г. № 52-Ф3) // С3 РФ. 1999. № 26. Ст. 3176 (утратил силу).

19. Об общих принципах организации законодательных (представительных) и исполнительных органов государственной власти субъектов Российской Федерации: Федер. закон от 6 окт. 1999 г. № 184-ФЗ (в ред. от 5 февр. 2018 г. № 15-ФЗ) // СЗ РФ. 1999. № 42. Ст. 5005; СЗ РФ. 2018. № 7. Ст. 975.

20. Глигич-Золотарева М.В. Теория и практика федерализма: системный подход / под ред. Н.М. Добрынина. Новосибирск, 2009.

21. О внесении изменений в Федеральный закон «О политических партиях» в связи с поэтапным снижением минимальной численности членов политических партий: Федер. закон от 28 апр. 2009 г. № 75-Ф3 // С3 РФ. 2009. № 18 (1 ч.). Ст. 2155.

22. О внесении изменений в отдельные законодательные акты Российской Федерации в связи со снижением минимального процента голосов избирателей, необходимого для допуска к распределению депутатских мандатов в Государственной Думе Федерального Собрания РФ: Федер. закон от 20 окт. 2011 г. № 287-Ф3 // С3 РФ. 2011. № 43. Ст. 5975.

23. О внесении изменений в Федеральный закон «Об общих принципах организации законодательных (представительных) и исполнительных органов государственной власти субъектов Российской Федерации» и Федеральный закон «Об основных гарантиях избирательных прав и права на участие в референдуме граждан Российской Федерации»: Федер. закон от 2 мая 2012 г. № 40-Ф3 // Российская газета. 2012. 4 мая.

24. О внесении изменений в отдельные законодательные акты Российской Федерации: Федер. закон от 2 апр. 2013 г. № 30-Ф3 (в ред. от 3 февр. 2015 г. № 6-ФЗ) // СЗ РФ. 2013. № 14. Ст. 1638.

25. Об утверждении Договора о разграничении предметов ведения и полномочий между органами государственной власти Российской Федерации и органами государственной власти Республики Татарстан: Федер. закон от 24 июля 2007 г. № 199-Ф3 // СЗ РФ. 2007. № 31. Ст. 3996. 